\title{
PERAN GURU DI ERA REVOLUSI 4.0 DALAM UPAYA PENCEGAHAN PENYALAHGUNAAN NARKOBA DI MADRASAH IBTIDAIYAH
}

\section{TEACHERS' ROLE AS EFFORT TO PREVENT DRUG ABUSE AT ISLAMIC ELEMENTARY SCHOOL IN THE REVOLUTION 4.0 ERA}

\author{
Amir Hamzah ${ }^{1}$ Faisal $^{2}$, Fajri Ismail ${ }^{3}$ \\ ${ }^{123}$ Fakultas Ilmu Tarbiyah dan Keguruan UIN Raden Fatah Palembang \\ ${ }^{123}$ Jl. KH.Zainal Abidin Fikri KM 3.5 Palembang Sumatera Selatan \\ Email :Amirhamzah_uin@ \\ Fajriismail_uin@ radenfatah.ac.id ${ }^{3}$
}

Submitted:17-09-2020, Revised:01-12-2020, Accepted:04-12-2020

\begin{abstract}
Abstrak
Tujuan dari penelitian ini untuk menemukan perencanaan program pencegahan penyalahgunaan narkoba sejak di madrasah ibtidaiyah dan implementasi dari program pencegahan penyalahgunaan narkoba di madrasah ibtidaiyah. Penelitian ini menggunakan jenis penelitian kualitatif. Pengambilan data menggunakan wawancara mendalam, dokumentasi, dan observasi yang selanjutnya dianalisis yaitu data reduction, data display, dan conclusion drawing/verification. Hasil penelitian, antara lain: (1) perencanaan pencegahan penyalahgunaan narkoba, yaitu bekerjasama dengan pemerintah setempat, koordinasi dengan dinas terkait, bekerjasama dengan orang tua, kerjasama dengan stakeholder di madrasah, sosialisasi, pembuatan kantin sehat, pembatasan akses masuk madrasah, peningkatan materi dan praktik agama serta penciptaan suasana yang menyenangkan, dan (2) implementasi dari program yang dirancang, bekerjasama dengan pihak terkait, bekerjasama dengan orang tua baik secara tatap muka maupun via online, praktikum ibadah (shalat dhuha, shalat dhuhur, ekskul BTA, dan hafidz Qur'an), pembelajaran yang menyenangkan, dan penerapan pendidikan karakter, serta pelatihan ICT. Berdasarkan implementasi yang dilaksanakan sampai dengan saat ini, belum ada kasus penyalahgunaan narkoba yang terjadi di kalangan siswa di MI Tarbiyatul Ula Palembang.
\end{abstract}

Kata Kunci: Peran Guru, Revolusi 4.0, Narkoba

\begin{abstract}
This study aimed to find out the prevention plan programs of drug abuse and its implementation since madrasah ibtidaiyah. This research used qualitative research. Data collection was done in-depth interviews, documentation, and observations which then analyzed through data reduction, display data, and conclusion drawing verification. The results of the study included; (1) planning for drug abuse prevention by making collaboration with local governments, coordination with related agencies, cooperation with parents, collaboration with stakeholders in madrasahs, socialization, building healthy canteens, restricting access to madrasahs, improving materials and religious practices, and creating a pleasant atmosphere, and (2) implementation of designed programs, collaboration with related parties, collaboration with parents both face-to-face and via online, practicum of worship (dhuha prayer, dhuhur prayer, BTA extracurricular activities, and hafidz Qur'an), fun learning, and the application of character education and ICT training. Based on the implementation that had been carried out, there were no cases of drug abuse that have occurred among students at MI Tarbiyatul Ula Palembang.
\end{abstract}

Keywords: Role of Teachers, Revolution 4.0, Drugs 
How to Cite: Hamzah, A., Faisal, Ismail, F. (2020). Peran Guru di Era Revolusi 4.0 dalam Upaya Pencegahan Penyalahgunaan Narkoba di Madrasah Ibtidaiyah. AULADUNA: Jurnal Pendidikan Dasar Islam, 7(2), 124-135.

\section{Pendahuluan}

Teknologi perkembangannya sangat cepat dalam kehidupan di era modern, berdampak pada perubahan setiap individu maupun kelompok baik perubahan positif maupun negatif, perlunya pengawasan bagi siswa dan selektif dalam memilih pergaulan yang memiliki dampak panjang bagi setiap individu maupun kelompok. Madrasah ibtidaiyah merupakan lembaga pendidikan tingkat dasar sebagai tumpuan awal dalam membentuk karakteristik setiap siswa di dalamnya yang mengikuti proses pembelajaran di lingkungan madrasah maupun luar madrasah. Kunci keberhasilan proses pendidikan tingkat dasar salah satunya peran penting seorang guru. Peran guru sangat sentral dan perlu selektif dalam menyikapi setiap perkembangan dan informasi yang berkembang. Jika tidak memperhatikan pembentukan moral dalam mendidik, maka akan berdampak untuk masa depannya. Sekarang ini banyak para generasi muda yang masih kurang untuk memiliki karakter meskipun telah mengenyam pendidikan.

Revolusi industri digaungkan telah memasuki fase ke 4, persaingan kehidupan semakin luas dan bukan hanya terjadi dalam skala nasional tetapi sudah terjadi secara internasional. Setiap orang memiliki akses untuk berkomunikasi melalui media internet, kebebasan tanpa batas ini akan menjadi problem sendiri jika tidak disikapi dengan bijak, siswa dapat berlaku bijak apabila dibiasakan sejak dini.

Salah satu dari kemajuan revolusi industri 4.0 merupakan globalisasi. Dalam dunia pendidikan globalisasi ini mempunyai dampak positif dan dampak negatif. Salah satu dampak positif misalnya mendorong profesi baru seperti youtuber, blogger, instragramer, dan lain-lain. Sedangkan dampak negatifnya banyak sekali, terutama terjadi di kalangan anak usia sekolah dasar, misalnya merokok, mencuri, meminta uang secara paksa ke temannya, porno aksi, dan bentuk kenakalan lainnya. Beberapa contoh akibat dampak negatif yang marak terjadi di kalangan masyarakat menjadi tanggung jawab guru di era revolusi 4.0. Perlu adanya restorasi dalam pembelajaran yang menekankan pada perbaikan akhlak.

Berbagai ancaman yang dapat merusak generasi masa depan di era revolusi 4.0 sangat kompleks dari berbagai aspek sektor persaingan global yang semakin luas dan memiliki dampak negatif jika tidak pandai dalam menyikapi ancaman yang sangat mengintai setiap individu yang hidup di era revolusi industri 4.0. permasalahan yang belum ada titik terang untuk selesai adalah permaslahan narkoba. Narkoba merupakan singkatan dari narkotika dan obat/bahan berbahaya (Suyatna, 2018). Demikian pula di Indonesia, tidak ada satu provinsi bahkan kabupaten dan kota yang steril dari permasalahan narkoba. Pemerintahan Provinsi Sumatera Selatan (Sumsel) bersama dengan Badan Nasional Narkotika Provinsi Sumsel melakukan mapping (pemetaan) peredaran narkoba di Provinsi Sumsel. Hasilnya, dari 17 kabupaten atau kota di Sumsel, Kota Palembang menjadi kota yang memiliki kasus narkoba yang terus bertambah. Di Kota Palembang, pemetaan lebih mengerucut lagi. Dari data yang didapat, ada tiga kecamatan di Palembang yang rawan narkoba dan berpotensi menjadi kampung narkoba. Ketiga kecamatan tersebut adalah Kecamatan Gandus (khususnya di Lr Jambu, Lr Sailun), Kecamatan Ilir Timur I (13 Ilir dan 14 Ilir), dan Kecamatan Bukit Kecil (kawasan Rumah Susun). Dari hasil mapping yang dilakukan, tiga 
kecamatan di Palembang masuk ke dalam wilayah dengan tingkat peredaran narkoba tertinggi (Ika, 2019).

Hal ini juga diberitakan dalam koran tribun yang menyatakan bahwa Ariansyah yang berumur 17 tahun cukup mencengangkan. Dalam kurun waktu dua minggu, remaja tamatan SD tersebut mampu mengkonsumsi sabu paket kecil seharga Rp 100.00,00 sebanyak empat kali. Dalam jurnal napza, terdapat siswa SD yang sedang menjalani rehabilitasi di rumah sakit yang bekerjasama degan BNN(Sugiyarto, 2015). Melihat fenomena penyalahgunaan narkoba terhadap siswa semakin memperihatinkan. Siswa sekolah dasar merupakan pondasi awal masa depan anak dan masa keemasan anak (golden age). Jika mereka terkena narkoba, maka akan merusak akal dan kejiwaan mereka bahkan nantinya anak bisa sakit jiwa ataupun bodoh. Jika hal itu terjadi saat anak masih sekolah dasar, mau jadi apa negeri ini karena merekalah penerus bangsa ini yang akan datang. Melihat fenomena saat ini, semakin banyaknya pengguna narkoba di Indonesia yang semakin meluas jangkauannya, sehingga perkembangan narkoba yang semakin menghawatirkan.

Kontribusi pendidikan yang diharapkan bagi perkembangan siswa dijelaskan dalam undang-undang No. 20 tahun 2003 bab II pasal 3 yang menyatakan bahwa: pendidikan nasional berfungsi mengembangkan kemampuan dan membentuk watak serta peradaban bangsa, bertujuan untuk berkembangnya potensi siswa agar menjadi manusia yang beriman dan bertakwa kepada Tuhan yang Maha Esa, berakhlak mulia, sehat, berilmu, cakap, kreatif, mandiri, dan menjadi warga negara yang demokratis serta bertanggungjawab (Republik Indonesia, 2003).

Pendidikan memiliki hubungan resiprocal (timbal-balik). Pendidikan dan lingkungan masyarakat mempunyai hubungan yang erat. Gambaran pendidikan tercermin pada kondisi lingkungan karena lingkungan masyarakat memiliki pengaruh yang sangat besar dalam pendidikan. Realita kondisi masyarakat, baik aspek kemajuan, peradaban, dan sejenisnya tercermin dalam dunia pendidikannya. Oleh karena itu, majunya dunia pendidikan dapat dijadikan cermin majunya masyarakat dan dunia pendidikan yang amburadul juga dapat menjadi cermin terhadap kondisi masyarakat yang penuh persoalan.

Senada juga dengan pernyataan U.S. Department dalam Promising Strategies to reduce subtance abuse. Schools can play a powerful role in prevention as teachers and administrators often are the first to detect warning signs of possible drug problems, such as poor school attendance or declining academic performance. Prevention efforts should begin early and continue through adolescence, when pressure to drink, smoke, and use other drugs greatly increases. Without reinforcing skills and anti-drug norms, behavioral results diminish. Programs enhanced with "booster sessions," activities which follow up on the initial program,help prevent or delay the initiation of drinking,smoking, and using other drugs (Holder, 2000: 2).

Berdasarkan paparan dari US Department di atas dapat disimpulkan pencegahan harus dilaksanakan sejak dini sampai anak remaja, Sekolah memiliki peranan penting dalam upaya pencegahan penyalahgunaan narkoba sejak dini melihat gejala yang terjadi pada siswa seperti siswa tidak semangat belajar atau gejala lain yang umumnya di sebabkan oleh faktor brokenhome guru dapat melihat perkembangan siswa sehari-hari dalam proses pembelajaran.

Hal yang sama juga di ungkapkan, dalam United Nations Office on Drugs and Crime Vienna Education for drug abuse prevention in schools may be defined as the educational programmes, policies, procedures and other experiences that contribute to 
the achievement of broader health goals of preventing drug use and abuse. Education for drug abuse prevention should be seen to include both formal and informal health curricula, the creation of a safe and healthy school environment, the provision of appropriate health services and support as well as the involvement of the family and the community in the planning and delivery of programmes (Maman, 2004: 12). Pernyataan kantor Perserikatan Bangsa-Bangsa untuk penanganan narkoba dan kejahatan menyatakan pentingnya program pencegahan penyalahgunaan narkoba di Sekolah, dapat disimpulkan pentingnya pemahaman siswa dalam pencegahan penyalahgunaan narkoba di sekolah.

Pendidikan adalah bagian yang sangat penting dalam hidup dan menjadi keharusan bagi setiap orang yang hidup di dunia ini (Bhardwaj, 2016: 25). Guru memiliki peran yang cukup besar dalam proses perkembangan siswa. Guru dalam paradigma baru ini bukan hanya bertindak sebagai pengajar, tetapi juga sebagai motivator dan fasilitator proses belajar mengajar yang realisasi atau aktualisasi potensipotensi manusia agar dapat mengimbangi kelemahan pokok yang dimilikinya. Sehingga hal ini berarti bahwa pekerjaan guru tidak dapat dikatakan sebagai suatu pekerjaan yang mudah dilakukan oleh sembarangan orang, melainkan orang yang benar-benar memiliki wewenang secara akademisi, kompeten secara operasional, profesional dalam pekerjaan yang telah dipilih, dan memiliki tanggung jawab untuk mencapai tujuan pendidikan yaitu menjadikan manusia seutuhnya.

Melihat fenomena penyalahgunaan narkoba yang semakin memprihatinkan baik yang kita lihat via media cetak maupun eletronik belakangan ini membuat kita perlu mewaspadai dengan membekali siswa lebih baik, baik dari segi kognitif, afektif, dan psikomotorik, siswa madrasah ibtidaiyah merupakan pondasi awal masa depan anak masa keemasan anak (golden age), dunia baru bagi siswa keluar dari lingkungan keluarga untuk berinteraksi dengan madrasah jika mereka salah berteman, sebagaimana artikel dari Simangunsong (2015) yang mengungkapkan faktor penyebab penyalahgunaan narkoba terjadi karena antara lain: (1) faktor individu belum mampu untuk beradaptasi dengan lingkungan, baik lingkungan belajar maupun lingkungan masyarakat, mudah terpengaruh atau tidak teguh pendirian, selalu ingin terlihat lebih dari teman sebayanya, tidak berpikir panjang dampak yang ditimbulkan dari kegiatan negatif yang dilakukan dan kurang pemahaman tentang bahaya narkoba bagi diri sendiri dan keluarganya, (2) faktor keluarga, keluarga memiliki peran penting bagi siswa. Lingkungan keluarga yang pencandu cenderung akan memberikan efek negatif bagi siswa. Orang tua di rumah tidak menjalankan tugas dan fungsinya secara baik, sehingga kehangatan dan kasih sayang keluarga tidak terasa bagi setiap anak sehingga mencari pelarian keluar untuk mencari perhatian dari orang lain, dan (3) teman bermain memiliki peran besar bagi setiap individu jika ada yang menjadi pecandu cenderung untuk mempengaruhi teman yang lainya jika tidak mengikuti dianggap tidak setia kawan.

Di madrasah, siswa dikondisikan mengikuti pembelajaran yang menyenangkan jangan sampai mengalami depresi karena akibatnya akan fatal di kemudian hari. Bagaimana nasib negeri ini jika hal tersebut tidak segera untuk dicegah sendini mungkin agar siswa jauh dari penyalahgunaan narkoba, karena merekalah penerus bangsa ini yang akan datang dan menentukan masa depan Indonesia. Revolusi mental yang digaungkan oleh Presiden Jokowi menjadi tanggung jawab tersendiri bagi civitas akademika. Pendidikan di Indonesia untuk menjadikan bangsa Indonesia menjadi lebih baik, baik secara pengetahuan dan keterampilan untuk siap bersaing di era revolusi 4.0 yang telah dilaksanakan dan sikap yang baik untuk menjadikan siswa kembali kepada 
marwah bangsa Indonesia yang terkenal di dunia sebagai bangsa yang sopan dan santun. Berdasarkan uraian tersebut peneliti akan mendeksripsikan peran guru MI pada revolusi 4.0 dalam upaya pencegahan penyalahgunaan narkoba pada siswa MI Tarbiyatul Ula Kecamatan Gandus Kota Palembang.

\section{Metode Penelitian}

Jenis Penelitian yang digunakan dalam penelitian ini adalah penelitian kualitatif. Penelitian kualitatif diartikan sebagai penelitian yang menghasilkan data deskriptif berupa kata tertulis dan lisan dari orang-orang dan perilaku yang diamati dan bertujuan untuk menyumbangkan pengetahuan secara mendalam mengenai objek penelitian (Moleong, 2006: 4). Metode ini dipilih karena lebih mampu menemukan definisi situasi dan gejala sosial dari subyek, perilaku, motif-motif subyektif, perasaan, dan emosi orang yang diamati, merupakan definisi situasi subyek yang diteliti, sehingga subyek akan dapat diteliti secara langsung. Penelitian ini menggunakan pendekatan kualitatif, dikarenakan memiliki karakteristik sebagai berikut: (1) menggunakan makna, konteks, dan perspektif emik, (2) proses penelitian lebih berbentuk siklus daripada linear (pengumpulan dan analisa data berlangsung simultan), (3) lebih mengutamakan kedalaman daripada keluasan cakupan penelitian, (4) observasi dan wawancara mendalam bersifat sangat utama dalam proses pengumpulan data, dan (5) peneliti sendiri merupakan instrumen utama. Tidak hanya itu, peneliti juga mengamati secara berkala terhadap fenomena yang tampak, situasi serta kondisi dari obyek penelitian yang informasinya dapat diambil dari berbagai responden dan dokumen pendukung lainnya. Jenis penelitian ini merupakan jenis penelitian lapangan (field research) yang akan dilaksanakan di Madrasah Ibtidaiyah Gandus untuk mengetahui secara jelas kejadian yang sebenarnya yang terjadi di lapangan. Hal ini dilakukan untuk mempelajari secara intensif latar belakang, keadaan sekarang, dan interaksi lingkungan suatu unit sosial; individu, kelompok, lembaga atau masyarakat (Sugiono, 2010). Untuk memperoleh data secara holistik, integratif, dan memperhatikan relevansi data dengan fokus dan tujuan, maka peneliti memakai tiga teknik dalam pengumpulan data. Karena penelitian ini berbentuk kualitatif, maka datadata yang dibutuhkan harus berupa perkataan, catatan/tulisan, rekaman, gambar, dan lainnya. Selain dari pada itu, dalam penelitian ini juga terjadi proses pengamatan dan pemaknaan terhadap kasus atau permasalahan yang terjadi. Oleh sebab itu, data yang dikumpulkan berupa wawancara mendalam (deep interview) untuk mengumpulkan informasi berupa perkataan lisan (verbal), pengamatan (observation) untuk memahami sikap/tindakan yang terjadi, dan dokumentasi yang berupa tulisan, gambar, rekaman, atau foto. Analisis data adalah rangkaian kegiatan penelaahan, pengelompokan, sistematisasi, penafsiran dan verifikasi data agar sebuah fenomena memiliki nilai sosial, akademis, dan ilmiah. Analisis data untuk penelitian kualitatif dimulai sudah sejak di lapangan (Sugiono, 2010). Data-data yang dianalisis melalui beberapa tahapan-tahapan, sebagaimana yang dikemukakan Miles \& Huberman bahwa aktivitas dalam analisa data, yaitu data reduction, data display, dan conclusion drawing/verification. 


\section{Hasil dan Pembahasan}

\subsection{Hasil}

Setelah melaksanakan kegiatan penelitian di madrasah ibtidaiyah, peneliti menemukan jawaban dari permasalahan program pengembangan pencegahan penyalahgunaan narkoba dilakukan sejak masa madrasah ibtidaiyah karena pada masa ini anak madrasah ibtidaiyah akan merangkai masa depannya, semua yang terjadi pada masa ini diingat sampai tua.

Perencanaan pencegahan penyalahgunaan narkoba pada siswa madrasah ibtidaiyah dalam perencanaan pelaksanaan pencegahan penyalahgunaan narkoba di Madrasah Tarbiyatul Ula Kecamatan Gandus, membuat beberapa program sebagai upaya pencegahan penyalahgunaan narkoba sejak dini, untuk menghindari pengaruh negatif narkoba yang sangat destruktif bagi siswa di era revolusi 4.0. berdasarkan wawancara dengan Kepala Madrasah Tarbiyatul Ula. Beberapa program yang telah dibuat oleh madrasah ibtidaiyah yaitu, sebagai berikut:

a. Memanfaatkan Media Sosial

Pemanfaatan media sosial digunakan dalam upaya pencegahan sejak dini bagi siswa diantara media sosial yang akan digunakan oleh madrasah adalah membuat grup whatsaap dengan wali siswa, membuat panfage facebook dan web madrasah sebagai sarana informasi bagi siswa dan wali siswa yang ada di lingkungan madrasah ibtidaiyah. b. Melibatkan Pemerintah Setempat

Bekerjasama dengan instansi pemerintahan seperti ketua RT/RW dan kelurahan untuk bekerjasama mensosialisasikan kepada siswa dan masyarakat terkait bahaya penyalahgunaan narkoba, bekerjasama dengan puskemas terdekat dan polisi terdekat serta Badan Narkotika Nasional (BNN) kota Palembang mengingat permasalahan narkoba bukan hanya permasalahan Madrasah, tetapi semua elemen bertanggungjawab dalam perkembangan siswa yang aman jauh dari pengaruh buruk penyalahgunaan narkoba.

c. Melibatkan Orang Tua

Bekerjasama dengan orang tua baik ketika di lingkungan madrasah maupun luar madrasah pola kerjasama yang akan ditetapkan melaui media sosial, tatap muka langsung dan buku pantau sehingga siswa tetap terpantau perkembangan psikomotoriknya baik berada di lingkungan madrasah maupun di lingkungan rumah tempat siswa tinggal.

d. Kerja Semua Stakehoder Uang Ada di Madrasah

Program selanjutnya bekerjasama dengan semua stakeholder yang ada di madrasah seperti, penjaga madrasah, penjaga kantin dan semua dewan guru di lingkungan madrasah.

e. Kantin Sehat

Pembuatan kantin di lingkungan madrasah ibtidaiyah mensosialisasikan dan memantau anggota kantin dalam pemilihan makanan.

f. Pembatasan Akses di Lingkungan Madrasah Ibtidaiyah

Agar tidak semua masuk di lingkungan madrasah akses masuk akan di batasi hanya satu pintu masuk.

g. Sosialisasi Rutin

Setiap pembina upacara rutin memberikan sosialisasi bukan hanya lewat upacara, sosialisasi juga dapat dilaksanakan via mading madrasah dan ruang kelas siswa. 
Adapun implementasi pelaksanaan program pencegahan penyalahgunaan narkoba yang dilakukan di madrasyah ibtidiyah adalah sebagai berikut:

a. Kolaborasi orang tua dalam upaya pemantauan perkembangan anak di lingkungan luar madrasah dan dalam madrasah yang dilaksanakan oleh madrasah ialah dengan membuat buku pantau yang telah dibuat oleh guru serta melakukan komunikasi via Whatshap group wali kelas dan wali siswa.seperti yang dibuat oleh Ibu A membuat Whatsaap untuk memudahkan komunikasi dengan orang tua di era revolusi 4.0. guru rutin memberikan informasi kepada orang tua terkait perkembangan siswa selama di lingkungan madrasah.

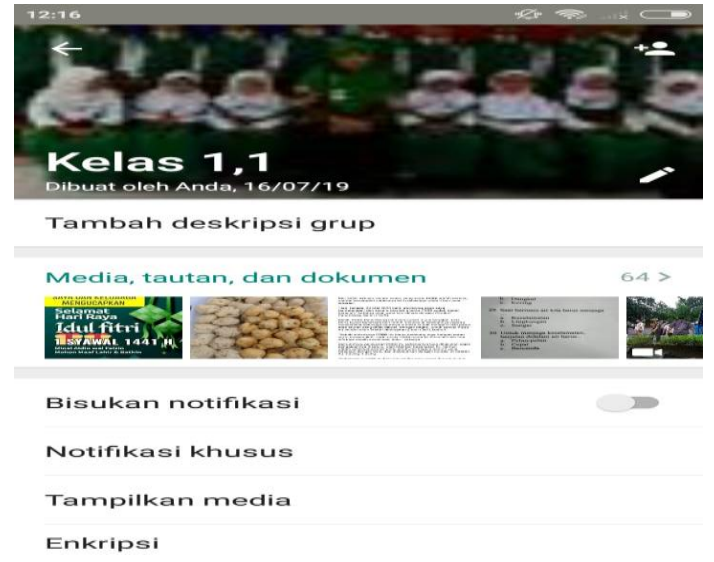

Gambar 1. POMG (Persatuan Orang Tua, Murid, dan Guru Kelas)

b. Memantau kantin sehat, di madrasah melihat makanan yang ada di kantin, siswa belum memahami pola makan sehat yang harus dikonsumsi karenanya perlu pemantauan secara rutin agar kesehatan siswa tetap terjaga. selama berada di lingkungan madrasah siswa menjadi tanggung jawab pihak madrasah, guru memastikan siswa aman dan nyaman selama siswa berada di lingkungan madrasah.

c. Menciptakan lingkungan sehat, lingkungan sehat yang diciptakan oleh pihak madrasah salah satunya menjadikan madrasah zona bebas rokok, dan polusi, sedini mungkin diberikan pemahaman kepada siswa untuk tidak mencoba-coba merokok dalam hal ini semua guru ataupun stakeholder yang ada di lingkungan madrasah tidak diperkenankan untuk merokok di area madrasah seperti pada mading yang tertera di bawah ini.

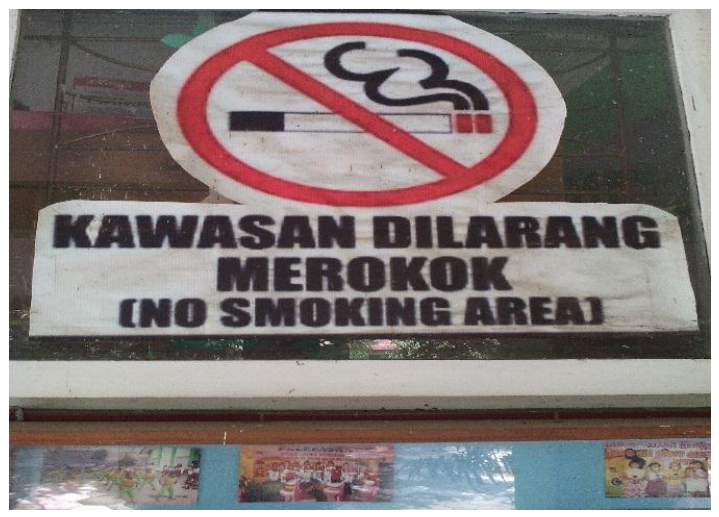

Gambar 2. Mading MI tertera stiker Bebas Rokok 
d. Sosialisasi rutin kepada siswa dan seluruh civitas akademika di madrasah ibtidaiyah melalui kegiatan upacara hari senin pembina rutin mengingatkan kepada siswa untuk menjauhi rokok, obat-obat terlarang mengurangi bermain handphone selama di lingkungan rumah selain sosialisasi secara rutin juga rutin ditempel di mading informasi bahaya rokok dan bahan lainya yang membawa dampak buruk bagi masa depan siswa di lingkungan madrasah. Contoh yang baik di lingkungan madrasah sebagai upaya dalam pencegahan terhadap perbuatan negatif yang dilakukan siswa karakter siswa meniru apa yang dilihat dalam kehidupan sehari-hari.

e. Pendidikan karakter yang diterapkan di madrasah diantaranya karakter religius, disiplin, dan tanggung jawab. Pentingnya penerapan pendidikan karakter sejak dini untuk menanamkan moral yang baik bagi siswa. Pendidikan karakter yang sudah diterapkan di madrasah ibtidaiyah adalah sebagai berikut:

1) Agama sejak dini agar selalu ingat mana yang baik ataupun sebaliknya, upaya yang dilaksanakan oleh pihak madrasah ialah melalui shalat dhuha berjamaah, ekskul baca tulis Al-Qur'an, ekstrakulikuler tahfidz Qur'an, shalat dhuhur berjamaah, dan private ilmu keagamaan (fiqih, sejarah kebudayaan Islam, Qur'an hadits, dan aqidah akhlak).

2) Disiplin merupakan salah satu kunci kesuksesan dalam proses pembelajaran maupun di luar pembelajaran upaya yang dilakukan oleh pihak madrasah ialah membiasakan disiplin masuk tepat waktu dan tidak ada toleransi pengumpulan tugas yang diberikan oleh guru.

3) Tanggung jawab perlu adanya tanggung jawab yang ditanamkan sejak dini upaya dari madrasah dalam membuat siswa berani bertanggung jawab memberikan tugas upacara, melaksanakan event seperti hari besar Islam di bentuk panitia dari unsur siswa agar siswa berani tangung jawab.

f. Pembelajaran strategi aktif learning dalam pembelajaran di madrasah. Madrasah menggunakan kurikulum 2013 yang dilakukan oleh pihak madrasah belajar dengan menggukan berbagai metode yang bervariasi yang menarik sehingga siswa nyaman ketika proses pembelajaran dilakukan. Pembelajaran di kelas mengenai pencegahan narkoba di sekolah kurikulum yang diterapkan melengkapi siswa untuk terbebas dari narkoba, jika dalam penelitian sebelumnya hanya pengenalan kurikulum dalam hasil penelitian ini pada kurikulum dan implementasinya di dalam kelas.

g. Pelatihan IT dilaksanakan agar guru melek teknologi sebagai upaya pemahaman teknologi agar mampu memahami pola kehidupan yang dilaksanakan di era revolusi industri 4.0. Berbagai tantangan kompleks yang dihadapi pendidik di era revolusi 4.0. Salah satunya pengaruh buruk narkoba yang menyebar melalui kebebasan teknologi yang sedang dihadapi ketika jam istirahat yang belum jelas atau belum menguasai ICT bertanya pada guru lainya.

Dari rangkaian program yang dilaksanakan hasilnya sampai dengan selesainya penelitian ini tidak ada kasus yang terjadi di kalangan siswa di Madrasah Ibtidaiyah Tarbiyatul Ula Palembang. Pentingnya pencegahan sejak dini agar penerus bangsa bebas dari penyalahgunaan narkoba dan Indonesia menjadi negara yang bebas narkoba yang menjadi harapan kita semua, salah satu faktor terjadinya penyalahgunaan narkoba selain lingkungan kurangnya pemahaman dari bahaya laten penyalahgunaan narkoba bagi masa depan siswa dan keluarganya. 


\subsection{Pembahasan}

Hasil penelitian yang telah dilaksanakan menunjukan ada program yang dibuat oleh madrasah di antaranya, memanfaatkan media sosial, bekerjasama dengan instansi terkait, kerjasama dengan semua elemen terkait. Bekerja sama dengan pihak-pihak terkait dan tanggap dalam upaya pencegahan penyalahgunaan narkoba di madrasah ibtidaiyah, mengingat dampaknya yang begitu destruktif, penyalahgunaan narkoba di kalangan pelajar harus dilihat sebagai masalah kolektif dan dihadapi secara kolektif pula, dengan melibatkan semua pihak terkait langsung atau pun tidak langsung dengan institusi sekolah berada (Tobing \& Hutabarat, 2007: 9).

Hal ini juga yang diprogramkan oleh pihak madrasah dan sudah berjalan bekerjasama dengan pemerintah setempat. Implementasi dari program pencegahan penyalahgunaan narkoba bagi siswa madrasah adalah sosialisasi. Sosialisasi kepada semua masyarakat yang ada di madrasah, mensosialisasikan kepada siswa tentang pencegahan penyalahgunaan narkoba, faktor penyebab orang menyalahgunaan narkoba adalah ketidakpahaman seseorang terhadap narkoba (Afiatin, 2010: 52). Di madrasah ibtidaiyah melakukan sosialisasi kepada siswa melalui mading, upacara hari senin dan kegiatan yang dihadiri oleh semua stakeholder madrasah ibtidaiyah. Selanjutnya berkolaborasi dengan orang tua, kerjasama dengan orang tua dalam segala hal untuk kemajuan perkembangan anak baik sikap, keterampilan dan pengetahuan anak. Di dalam Islam kerjasama dalam kebaikan pun di anjurkan seperti yang dijelaskan dalam Al-Qur'an surat Al-Maidah ayat 2.

Esa Mulyasa menjelaskan guru sebagai pendidik dan pembimbing ketika berada di lingkungan sekolah dan orang tua sebagai pendidik ketika anak berada di lingkungan keluarga (Mulyasa, 2003: 161). Menciptakan lingkungan sekolah memberikan anakanak lingkungan dan fasilitas yang baik, memberikan perlindungan pada siswa di sekolah dan memberi makan otaknya dengan makanan yang sehat dan bergizi berupa pemikiran-pemikiran yang mendidik (Devi, 2007: 15). Menurut undang-undang kesehatan nomor 36 tahun 2009 tentang kesehatan, kesehatan adalah keadaan sehat, baik secara fisik, mental, spiritual, maupun sosial yang memungkinkan setiap orang untuk hidup produktif secara sosial dan ekonomis (Republik Indonesia, 2009). Di madrasah ibtidaiyah hanya pedagang kantin yang mentaati aturan dan siap dicek oleh puskesmas, makanan yang disiapkan apakah sehat bagi siswa atau sebaliknya.

Pendidikan karakter di madrasah, pembiasaan siswa untuk berperilaku baik perlu ditunjang oleh keteladanan guru dan kepala madrasah.Oleh karena itu, pada hakikatnya metode atau model pembiasaan dalam pendidikan karakter tidak dapat dipisahkan dari keteladanan. Di sana ada pembiasaan ada keteladanan dan sebaliknya di sana ada keteladanan, di sana ada pembiasaan, yang nantinya akan membentuk karakter (Mulyasa, 2003). Berdasarkan hasil penelitian, diperoleh bahwa hubungan pendidikan dengan karakter disiplin terjadi secara positif dan terdapat hubungan pendidikan dengan karakter tanggung jawab. Oleh karena itu, hasil penelitian ini menunjukkan adanya hubungan yang signifikan antara pendidikan dengan karakter disiplin dan tanggung jawab dalam perspektif guru. Berdasarkan hasil uji penelitian di madrasah ibtidaiyah yang terletak di Kecamatan Tajurhalang ini, dapat disimpulkan bahwa terdapat hubungan yang sedang antara variabel pendidikan dengan karakter disiplin dan tanggung jawab.

Bisa disimpulkan bahwasannya jika pendidikan semakin bermutu, maka karakter disiplin dan tanggung jawab pada siswa juga akan meningkat (Nurmala, Dahlan, \& Sobari, 2020: 10). Hal itu juga yang terjadi di Madrash Ibtidaiyah Tarbiyatul Ula, 
penekanan disiplin dan tanggung jawab dibiasakan sejak dini agar siswa mampu bertanggung jawab untuk dirinya sendiri, keluarga, dan lingkungan sekitarnya. Menjadi role model disiplin untuk adiknya di rumah dan adik kelas sebagai upaya pencegahan sejak dini penyalahgunaan narkoba di masa mendatang, pembiasaan ini penting karena yang di alami siswa madrasah ibtidaiyah akan selalu ada di memori siswa sampai ia menjadi dewasa.

Penanaman pendidikan agama melalui BTA, ekstrakulikuler tahfidz, shalat dhuha berjamaah dan shalat dhuhur berjamaah hal tersebut mengacu pada undangundang nomor 20 tahun 2003 tentang SISDIKNAS, pasal 12, ayat (1) huruf a, mengamanatkan bahwa setiap siswa pada setiap satuan pendidikan berhak mendapatkan pendidikan agama sesuai dengan agama yang dianutnya dan diajarkan oleh pendidik yang seagama (Republik Indonesia, 2003). Hal senada juga dengan hasil penelitian Hariandi, Putri, Audria, Puspitasari, \& Mutmainah (2019: 196) yang menunjukkan bahwa pembelajaran Pendidikan Agama Islam (PAI) dalam menanamkan nilai karakter religius dan nasionalisme di sekolah dasar adalah menerapkan karakter dengan membiasakan siswa mengucap salam, berdoa, membaca surah yasin, menjalankan ibadah, selalu bersyukur, tidak menyontek ketika ujian atau ulangan, mengumpulkan tugas tepat waktu, bersikap tiga S (senyum, sapa, dan salam), menerapkan karakter sikap toleransi, tanggung jawab, kerja keras, sopan santun, sikap gotong royong, dan peduli sosial, serta kedisiplinan. Perbedaan dengan hasil peneltian ini adalah shalat dhuha berjamaah, eksul tahfidz Qur'an dan pembelajaran pokok madrasah seperti AlQur'an hadits, fiqih, aqidah akhlak, sejarah kebudayaan Islam yang setiap minggu di pelajari oleh siswa madrasah ibtidaiyah.

Pembelajaran (learning) merupakan pengaruh permanen atas perilaku, pengetahuan, dan keterampilan berpikir yang di peroleh melalui pengalaman (Santrock, 2007: 266). Implementasi dari program pencegahan penyalahgunaan narkoba di madrasah ibtidaiyah ialah melalui pembelajaran di dalam kelas. Menurut Hergenhan \& Olson (2008: 4), belajar merupakan perubahan tingkah laku, hasil dari proses belajar harus selalu diterjemahkan ke dalam perilaku atau tindakan yang dapat diamati, setelah menjalani proses belajar, pembelajar (learner) akan mampu melakukan sesuatu yang tidak bisa mereka lakukan sebelum mereka belajar. Hal ini juga senada dengan yang di utarakan Maman (2004) bahwa dalam pencegahan narkoba di sekolah kurikulum yang diterapkan melengkapi siswa untuk terbebas dari narkoba, jika dalam peneltian sebelumnya hanya pengenalan kurikulum dalam hasil penelitian ini pada kurikulum dan implementasinya di dalam kelas.

Secara objektif tidak dapat dipungkiri bahwa revolusi industri 4.0 menimbulkan tantangan besar yang harus dihadapi bagi entitas diri, khususnya bidang pendidikan. Dampak dari digital teknologi menuju revolusi 4.0 adalah memiliki jati diri dan mempersiapkan mental dan skill yang unggul. Cara yang paling utama untuk mempersiapkan keahlian tersebut harus memiliki perilaku yang baik dan meningkatkan kompetensi diri (Winarni et al., 2016: 453). Pemahaman agama yang baik dan akhlak yang akan menjadi bekal siswa dalam menghadapi era revolusi 4.0. Siswa digembeng agar tidak terpengaruh pada hal yang negatif dampak dari kebebasan teknologi.

\section{Simpulan}

Berdasarkan hasil penelitian dapat disimpulkan, antara lain: (1) sudah ada program yang dibuat oleh Madrasah Ibtidaiyah Tarbiyatul Ula dalam upaya pencegahan penyalahgunaan narkoba namun hidden curriculum program yang sudah di rancang 
yaitu bekerjasama dengan instansi terkait, kerjasama dengan orang tua/wali siswa membuat lingkungan sehat, penekanan pendidikan karakter, pembelajaran yang menyenangkan dan kembali kepada Al-Qur'an program baca tulis Al-Qur'an, dan (2) implementasi dari program yang telah di rancang oleh Madrasah Ibtidaiyah Tarbiyatul Ula sudah berjalan maksimal dalam upaya pencegahan penyalahgunaan narkoba. Program yang sudah terealisasi di antaranya kerjasama dengan orang tua atau wali siswa, kerjasama dengan instansi terkait, kerjasama dengan seluruh civitas akademika madrasah, pembatasan akses masuk madrasah, pembuatan kantin sehat, penerapan pendidikan karakter yang diterapkan di madrasah karakter religius, disiplin dan tanggung jawab semua karakter telah di implementasikan namun penekannya lebih pada karakter religius, disiplin dan tanggung jawab, pembelajaran yang berpusat pada siswa, tahfidzul Qur'an, dan pelatihan Internet Comunication Technology (ICT).

Pentingnya pencegahan sejak dini mengingat bahayanya yang begitu kompleks pemahaman ditanamkan sejak dini agar generasi penerus bangsa terbebas dari bahaya penyalahgunaan narkoba, sejatinya pendidikan bukan hanya transfer of knowldege saja tetapi lebih dari itu bagaimana menyiapkan generasi penerus bangsa yang memiliki budi luhur sesuai dengan cita-cita bangsa Indonesia, memiliki karakter yang luas dan dapat membawa perubahan kearah yang lebih baik, baik untuk dirinya, keluarga, masyarakat, bangsa dan negara, setiap madrasah/sekolah perlu adanya sosialisasi pada siswa agar siswa mengetahui bahaya penyalahgunaan narkoba di kalangan pelajar, orang tua juga terlibat aktif banyak penyalahgunaan karena latar belakang orang tua yang brokenhome, dengan kerjasama semua pihak dan perhatian yang lebih tentang bahaya penyalahgunaan narkoba. Mudah-mudahan generasi penerus bangsa terbebas dari penyalahgunaan di era revolusi 4.0 yang akan memasuki revolusi 5.0. persiapan serius harus dilakukan agar generasi bangsa bukan hanya sebagai penonton di era revolusi 5.0.

\section{Daftar Pustaka}

Afiatin, T. (2010). Pencegahan Penyalahgunaan Narkoba dengan Program AJI. UGM Press.

Bhardwaj, A. (2016). Importance of Education in Human Life: A Holistic Approach. International Journal of Science and Consciousness, 2(2), 23-28. http://ijsc.net/docs/issue4/importance-of-education-in-human-life.pdf

Devi, S. (2007). Jadilah Pembimbing dan Guru bagi Putra Putri Anda Panduan Emosi dan Keterampilan. Nuansa.

Hariandi, A., Putri, M., Audria, N., Puspitasari, R., \& Mutmainah, F. (2019). Peranan Pembelajaran Agama Islam dalam Menanamkan Nilai Karakter Religius dan Nasionakisme Siswa Sekolah Dasar. AULADUNA: Jurnal Pendidikan Dasar Islam, 6(2), 196-204. https://doi.org/10.24252/auladuna.v6i2a10.2019

Hergenhan, B. R., \& Olson, M. H. (2008). Theories of Learning. Prenada Media Group.

Holder, E. H. (2000). Promising Strategies to Reduce Substance Abuse. Departement of Justice.

Ika. (2019). Upaya Penanggulangan Pencegahan, Pemberantasan, Penyalahgunaan, dan Peredaran Narkoba. Palembang Pos.

Maman, T. (2004). School-Based Education for Drug Abuse Prevention. United Nations Office on Drugs and Crime Vienna.

Moleong, L. J. (2006). Metodologi Penelitian Kualitatif. PT. Remaja Rosdakarya.

Mulyasa, E. (2003). Manajemen Pendidikan Karakter. PT Bumi Aksara.

Nurmala, A., Dahlan, M., \& Sobari, A. (2020). Hubungan Pendidikan dengan Karakter 
dan Tanggung Jawab dalam Perspektif Guru. AULADUNA: Jurnal Pendidikan Dasar Islam, 7(1), 10-19. https://doi.org/10.24252/auladuna.v7i1a2.2020

Republik Indonesia. (2003). Undang-Undang Republik Indonesia Nomor 20 Tahun 2003 tentang Sistem Pendidikan Nasional. Sekretariat Negara.

Republik Indonesia. (2009). Undang-Undang Republik Indonesia Nomor 36 Tahun 2009 tentang Kesehatan. Sekretariat Negara.

Santrock, J. W. (2007). Psikologi Pendidikan. Prenada Media Group.

Simangunsong, J. (2015). Penyalahgunaan Narkoba di Kalangan Remaja (Studi Kasus pada Badan Narkotika Nasional Kota Tanjungpinang). Jurnal Umrah, 1-65. http://jurnal.umrah.ac.id/wp-content/uploads/gravity_forms/1ec61c9cb232a03a96d0947c6478e525e/2015/09/E-jurnal-jimmy.pdf

Sugiono. (2010). Metode Penelitian Kuantitatif, Kualitatif, dan $R \& D$. Alfabeta.

Sugiyarto. (2015). Remaja Tamatan SD Ini Konsumsi Sabu Seminggu Empat Kali. Tribunnews.Com. https://www.tribunnews.com/regional/2015/03/02/remajatamatan-sd-ini-konsumsi-sabu-seminggu-empat-kali

Suyatna, U. (2018). Evaluasi Kebijakan Narkotika pada 34 Provinsi di Indonesia. Sosiohumaniora - Jurnal Ilmu-Ilmu Sosial dan Humaniora, 20(2), 168-176. https://core.ac.uk/download/pdf/295384749.pdf

Tobing, J. H. L., \& Hutabarat, U. (2007). Nikmat Membawa Sengsara. Indonesia Publishing House.

Winarni, Santosa, S., \& Ramli, M. (2016). Penerapan Model Discovery Learning untuk Meningkatkan Oral Activities Siswa SMA Discovery Learning Model for Enhancing Oral Activities of High School Student. Bioedukasi: Jurnal Pendidikan Biologi, 9(2), 55-61. https://doi.org/10.20961/bioedukasiuns.v9i2.4220 